Arkhais, Vol. 06 No. 1 Januari-Juni 2015

\title{
VERBA PREDIKAT BAHASA REMAJA DALAM MAJALAH REMAJA
}

\section{Renadini Nurfitri}

\begin{abstract}
Abstrak. Bahasa remaja dapat dteliti berdasarkan aspek kebahasaannya, salah satunya adalah mengenai verba. Verba sangat identik dengan predikat. sebagaimana tugas predikat, yaitu menandai apa yang dinyatakan pembicara tentang subjek. Oleh karena itu, hampir sebagian besar predikat diisi oleh verba meski predikat juga dapat diisi oleh kelas kata lain, seperti nomina, adjektiva atau frasa preposisi. Berdasarkan analisis data yang dilakukan pada bahasa remaja dalam majalah remaja, diperoleh hasil penelitian: (1) Sembilan bentuk verba predikat, yaitu (a) verba dasar, (b) verba berprefiks, (c) verba bersufiks -an, (d) verba bersufiks -kan. (e) verba bersufiks -i, (f) verba bersufiks -in, (g) verba bereduplikasi, (h) verba berproses gabung, dan (i) verba majemuk. Berdasarkan kesembilan bentuk verba predikat tersebut, kemunculan terbanyak ialah verba berprefiks 100 data atau 28,17\%. (2) Enam tipe verba predikat berdasarkan ketransitifannya, yaitu (a) dwitransitif, (b) transitif, (c) dwi-intransitif, (d) intransitif, (e) dwi-ekuatif, dan (f) ekuatif. Dari keenam tipe verba predikat itu kemunculan paling banyak adalah verba transitif, yakni sebanyak 197 data atau sebesar 55,49\%. Banyaknya kemunculan ini menunjukan bahwa karakteristik verba predikat dalam bahasa remaja memiliki kecenderungan terhadap verba aktivitas yang memiliki sasaran.
\end{abstract}

Kata Kunci: Verba, Verba Predikat, Ketransitifan, Remaja.

\section{PENDAHULUAN}

Variasi bahasa yang digunakan dalam situasi tertentu disebut juga dengan ragam bahasa. Berdasarkan situasi keformalan, ragam bahasa dibagi atas ragam baku atau ragam resmi, dan ragam nonbaku atau ragam tak resmi. Ragam baku adalah bahasa Indonesia yang digunakan dalam situasi resmi atau formal baik lisan maupun tulis. Salah satu penggunaan bahasa yang kurang mengindahkan pengunaan bahasa ragam resmi atau ragam baku adalah penggunaan bahasa remaja yang terdapat dalam majalah remaja. Bahasa yang digunakan dalam majalah remaja adalah bahasa ragam lisan yang dituliskan sehingga bahasa dalam majalah remaja cenderung menggunakan ragam nonbaku.

Fenomena seperti itu merupakan sebuah fakta kebahasaan yang terjadi langsung dalam masyarakat, khususnya pada media tulis seperti majalah remaja. Namun, hal itu tidak perlu dipandang sebagai wujud penyelewengan atau bahkan penggugatan terhadap bentuk-bentuk bahasa yang dibakukan. Fenomena seperti itu merupakan sebuah dinamika yang sudah sepantasnya dipersilakan terus hidup dan berkembang dalam lingkungan perkembangan dan lingkup hidupnya sendiri, tanpa harus dicampuradukkan dengan perihal keformalan dan kebakuan bentuk kebahasaan.Berikut beberapa contoh bahasa remaja dalam majalah remaja:

1. Aku selalu berusaha untuk buang sampah pada tempatnya. Bahkan kalau lihat ada sampah berserakan kadang suka aku ambil dan buang di tempat sampah. Setiap belanja ke minimarket, aku juga selalu bawatote bag buat nyimpan belanjaanku. Jadi nggak usah buang-buang plastik lagi. Menurutku perbuatan simple seperti ini berguna banget untuk menjaga lingkungan kita. 
2. Punya pendirian, peduli sesama, berkomitmen dan bisa bertanggung jawab. Menurut aku, gentleman punya sifat yang seperti itu. Kalau punya pacar, dia akan mementingkan ceweknya. Membawakan barang atau belanjaannya tanpa disuruh juga contoh sikap gentleman dalam kehidupan sehari-hari.

3. CL, Park Bom, Sandara dan Minzy, mengguncang Jakarta dengan aksi panggung mereka yang sangat spektakuler! Penampilan yang seksi, enerjik dan bersemangat, membuat para penonton yang hadir gak henti-hentinya melompat ngikutin irama lagu. Dan yang membuat konser ,All Or Nothing 2NE1 " kali ini special adalah keempatnya memberi kejutan dengan muncul di tengah-tengah penonton festival saat bawain lagu Lonely.

Pada ketiga contoh di atas, terdapat predikat yang diisi oleh kelas kata verba. Pada contoh pertama, fungsi predikat diisi oleh verba bawa, yaitu verba dasar yang belum melalui proses morfologis. Verba bawa menuntut hadirnya objek di belakang predikat. Dalam contoh 1, objek ditempati oleh frasal nominal tote bag. Konstituen objek berperan sebagai pelengkap informasi.

Selanjutnya, verba membawakan merupakan verba dasar bawa yang telah mengalami proses afiksasi me- dan -kan sehingga verba membawakan menuntut hadirnya dua konstituen di belakang predikat. Dengan adanya afiksasi me- dan -kan, verba bawa yang sebelumnya hanya menuntut satu konstituen, sekarang verba membawakan menuntut hadirnya dua konstituen wajib di belakang predikat. Sementara itu, pada contoh tiga verba bawain juga menuntut hadirnya dua konstituen di belakang predikat. Namun, pada contoh (3) hanya terdapat satu konstituen di belakang predikat, yaitu konstituen objek sehingga informasi yang diterima belum lengkap. Jadi, konstituen yang kehadirannya bersifat wajib dengan posisi mengikuti verba predikatnya itu ditentukan oleh bentuk-bentuk sufiks yang melekat pada bentuk verba dasarnya. Verba bawa yang hanya menuntut satu konstituen di belakang predikat, setelah ditambahkan sufiks -kan atau -in menjadi menuntut hadirnya dua konstituen di belakang predikat. Apabila hal itu belumterpenuhi, informasi yang tercantum dalam klausa tersebut belum lengkap. Konstituen yang kehadirannya bersifat wajib dan berperan dalam hal melengkapi makna verba suatu klausa atau kalimat agar informasi menjadi lengkap itu disebut dengan pemerlengkapan atau komplementasi (Sugono dan Indiyastini, 1994: 17). Pemerlengkapan dapat berupa objek, pelengkap, ataupun keterangan.

Dinamika bahasa pada bahasa remaja khususnya dalam majalah remaja seperti fenomena di atas dapat diteliti dari aspek kebahasaannya. Dalam rangka pembinaan dan pengembangan bahasa Indonesia, penelitian aspek-aspek kebahasaan perlu terus dilakukan secara berencana (Sugono dan Indiyastini, 1994: 1). Salah satu aspek kebahasaan yang menarik dari contoh mengenai bahasa remaja dalam majalah remaja, yaitu mengenai verba. Pembahasan verba dalam kajian kebahasaan selalu menarik perhatian karena kekayaan bentuk dan perilaku sintaksisnya dalam suatu konstruksi bahasa. Kehadiran suatu verba akan menentukan kehadiran unsur lain dalam kalimat sehingga penggunaannya sangat produktif dalam berkomunikasi. Dapat dikatakan bahwa hampir semua tataran linguistik, yakni morfologi, sintaksis, dan semantik berkaitan dengan verba sebagai objek kajian. Lantaran hal itulah verba mempunyai peranan penting dalam sebuah konstruksi kalimat atau klausa. Adapula verba sering dikaitkan dengan predikat. Bahkan, tidak jarang istilah yang dipakai untuk menyebut satuan fungsional predikat adalah verba. Penggunaan istilah verba sebagai pengganti istilah predikat didasarkan atas pertimbangan teori neurologi tentang fungsi otak (Aritonang, dkk. 2000: 7). 
Dengan demikian, fenomena kebahasaan mengenai bahasa remaja dalam majalah remaja diteliti lebih lanjut berdasarkan aspek-aspek kebahasaannya, yaitu mengenai verba predikat kaitannya dengan bentuk-bentuk verba, verba sebagai pengisi predikat yang memerlukan pemerlengkapan. Berdasarkan batasan masalahdiatas, dirumuskanmasalahsebagai berikut, "Bagaimana verba predikat bahasa remaja dalam majalah remaja Gadis, Wonder Teen, Hai, danGaul?". Selain itu, penelitian ini bertujuan untuk mendeskripsikan mengenai verba predikat bahasa remaja dalam majalah remaja Gadis, Wonder Teen, Hai, dan Gaul?

\section{METODE PENELITIAN}

Metode yang digunakan dalam penelitian ini adalah metode deskriptif kualitatif dengan teknik analisis isi. Penelitian ini diambil dari penggunaan bahasa remaja dalam majalah remaja Gadis, Wonder Teen, Hai, dan Gaul. Majalah yang dijadikan sebagai sumber data adalahsebanyak sepuluh eksemplar. Instrumen penelitian adalah peneliti sendiri dan dibantu dengan tabel analisis kerja. Adapun analisis didasarkan atas teori-teori linguistik sebagaimana dikemukakan pada bagian Kerangka Teori. Data diklasifikasikan berdasarkan bentuk dasar, berprefiks, bersufiks -an, bersufiks - $k a n$, bersufiks - $i$, bersufiks in, reduplikasi, proses gabung, dan majemuk.

\section{HASIL DAN PEMBAHASAN}

\section{Bentuk-Bentuk Verba}

Dari hasil analisis data, klausa yang mengandung verba predikat dengan bentuk verba dasar adalah sebanyak 91 data. Verba predikat pada klausa (1) merupakan bentuk verba dasar yang tidak mengalami pelesapan morfem. Verba datang tidak dapat ditampilkan dalam konteks berafiks, seperti *mendatang. Dari hasil analisis data, klausa yang mengandung verba predikat dengan bentuk verba berprefiks adalah sebanyak 100 data. Dalam penelitian ini ditemukan bentuk verba berprefiks tanpa sufiks baik berupa verba aktif maupun pasif. Prefiks-prefiks yang ditemukan antara lain, me $(N)$-, ber-, ter-, $k e-, d i$-.

Dalam data penelitian, klausa yang mengandung verba predikat dengan bentuk verba bersufiks - an hanya terdapat sebanyak 15 data.

Contoh:

(4) pasangan ini nggak pacaran

(5) (aku) kehilangan teman-teman dekatku

Verba predikat pada klausa (4) merupakan bentuk pelesapan dari verba berpacaran. Bentuk pacaran tidak termasuk dalam kelas kata verba, tetapi termasuk dalam nomina. Oleh karena itu,verba pacaran jika dilihat sebagai konstituen klausa dapat dimasukkan ke dalam bentuk verba predikat yang telah mengalami pelesapan morfem penanda aktif ber-. Lalu verba predikat pada klausa (5) adalah verba yang bersufiks -an. Karena verba kehilangan merupakan bagian dari konfiks ke--an.

Dari hasil analisis data, klausa yang mengandung verba predikat dengan bentuk verba berprefiks adalah sebanyak 73 data. Dalam penelitian ini ditemukan bentuk verba bersufiks -kan baik berupa verba aktif maupun pasif.

Contoh:

(6) aku dan ketujuh temanku menemukan tebing

(7) me time itu gue butuhkan 
Verba predikat pada klausa (6) merupakan bentuk verba untuk klausa aktif, sedangkan verba predikat pada klausa (7) adalah bentuk pasif dari membutuhkan.

Dalam data penelitian, klausa yang mengandung verba predikat dengan bentuk verba bersufiks- $i$ hanya terdapat sebanyak 23 data.

Contoh:

(8) aku nggak terlalu suka mengikuti tren-tren baru yang muncul

(9) konser 2NE1 ini dipenuhi penonton dari berbagai kategori

Verba predikat pada klausa (8) merupakan bentuk verba dalam klausa aktif, sedangkan verba predikat pada klausa (9) adalah verba dalam konstruksi pasif.

Dari hasil analisis data, klausa yang mengandung verba predikat dengan bentuk verba bersufiks -in adalah sebanyak 38 data. Bentuk verba ini banyak ditemukan dalam ragam nonbaku, seperti halnya dalam majalah remaja. Verba bersufiks -in memiliki padanan makna dengan sufiks $-i$ atau -kan. Dalam data penelitian, klausa yang mengandung verba predikat yang memiliki bentuk reduplikasi tanpa penggabungan dengan afiksasi adalah sebanyak 2 data. Dalam data penelitian, klausa yang mengandung verba predikat dengan bentuk verba berproses gabung (afiksasi dan reduplikasi) terdapat sebanyak 5 data. Dalam data penelitian, klausa yang mengandung verba predikat dengan bentuk verba majemuk terdapat sebanyak 9 data.

\section{Verba Predikat}

Berdasarkan fungsinya dalam akar klausa, verba diklasifikasikan ke dalam enam jenis ketransitifan, yaitu: verba dwitransitif, verba transitif, verba dwi-intransitif, verba intransitif, verba dwi-ekuatif, dan verba ekuatif.

Verba dwitransitif adalah verba yang berfungsi sebagai predikat dalam akar klausa dwitransitif. Predikat dalam akar klausa dwitransitif memerlukan dua unsur wajib di belakang predikat, yaitu hadirnya peran pelaku, penderita, dan skup. Verba transitif adalah verba yang berfungsi sebagai predikat dalam akar klausa transitif. Predikat dalam akar klausa transitif memerlukan satu unsur wajib di belakang predikat, yaitu hadirnya peran pelaku, dan penderita. Verba dwi-intransitif adalah verba yang berfungsi sebagai predikat dalam akar klausa dwi-intransitif. Predikat dalam akar klausa dwi-intransitif memerlukan hadirnya peran pelaku dan hadirnya peran skup atau dapat diperluas dengan skup. Verba intransitif adalah verba yang berfungsi sebagai predikat dalam akar klausa intransitif. Predikat dalam akar klausa intransitif hanya memerlukan hadirnya peran pelaku.

Verba dwi-ekuatif adalah verba yang berfungsi sebagai predikat dalam akar klausa dwi-ekuatif. Komplemen dalam akar klausa dwi-ekuatif tidak memerlukan hadirnya peran-subjek-item--tetapi memerlukan hadirnya peran skup atau dapat diperluas dengan skup. Verba ekuatif adalah verba yang berfungsi sebagai predikat dalam akar klausa ekuatif. Komplemen dalam akar klausa ekuatif tidak memerlukan hadirnya peran pelaku--subjek-item-- ataupun skup.

\section{KESIMPULAN}

Berdasarkan deskripsi data, hasil analisis data, interpretasi, dan pembahasan tentang verba predikat bahasa remaja dalam majalah remaja dapat ditarik kesimpulan bahwa dari 10 eksemplar majalah, yaitu Gadis, Wonder Teen, Hai, dan Gaul, diperoleh 9 jenis verba dari segi bentuk, yaitu verba dasar, verba berprefiks, verba bersufiks -an, verba bersufiks - $k a n$, verba bersufiks $-i$, verba bersufiks -in, verba bereduplikasi, verba berproses gabung, dan verba majemuk. 
Arkhais, Vol. 06 No. 1 Januari-Juni 2015

Berdasarkan bentuk-bentuk verba tersebut ditemukan sufiks -in yang lazim digunakan dalam ragam nonbaku. Sufiks -in digunakan sebagai pengganti sufiks - $i$ atau sufiks -kan. Oleh demikian itu, verba yang digunakan remaja dalam majalah remaja sebagian besar adalah bahasa ragam percakapan. Selain digunakannya ragam cakapan, bahasa yang digunakan dalam majalah remaja juga banyak menggunakan bentuk yang singkat-singkat. Hal itu terbukti dengan banyaknya kemunculan dari verba berprefiks dan verba dasar.

Sementara itu, dalam majalah remaja ditemukan 6 tipe verba predikat, yaitu verba dwitransitif, verba transitif, verba dwi-intransitif, verba intransitif, verba dwi-ekuatif, dan verba ekuatif. Verba transitif menjadi tipe verba predikat yang paling banyak muncul. Hal itu menujukkan bahwa remaja menyukai aktivitas atau kegiatan yang memiliki sasaran. Berdasarkan enam tipe verba predikat tersebut pemerlengkapan objek menjadi pemerlengkapan dengan kemunculan terbanyak. Hal itu pun berbanding lurus dengan kemunculan terbanyak dari verba transitif dan verba berprefiks. Dengan demikian karakteristik verba predikat bahasa remaja dalam majalah remaja memiliki kaitan erat dengan konstruksi SPO.

\section{DAFTAR RUJUKAN}

Achmad H. P. 2012. Sintaksis Bahasa Indonesia. Jakarta: Pustaka Mandiri.

Alwi, Hasan dkk. 2003. Tata Bahasa Baku Bahasa Indonesia. Jakarta: Balai Pustaka.

Aritonang, Buha dkk. 2000. Verba dan Pemakaiannya dalam Bahasa Indonesia. Jakarta: Pusat Bahasa.

Badudu, Abdul Muis dan Herman. 2005. Morfosintaksis. Jakarta: Rineka Cipta.

Chaer, Abdul.2007. Linguistik Umum. Jakarta: Rineka Cipta.

Diah, Mohammad. 1999. Morfosintaksis Bahasa Mantang. Jakarta: Pusat Pembinaan dan Pengembangan Bahasa.

Keraf, Gorys. 1991. Tata Bahasa Rujukan. Jakarta: Grasindo.

Kridalaksana, Harimurti. 2007. Pembentukan Kata dalam Bahasa Indonesia. Jakarta: Gramedia Pustaka Utama.

Muslich, Masnur. 2010. Garis-Garis Besar Tata Bahasa Baku Bahasa Indonesia. Bandung: Refika Aditama.

Rahardi, Kunjana. 2006. Bahasa Kaya Bahasa Berwibawa. Jakarta: Andi.

Sehandi Yohanes, Yan. 1991. Tinjauan Teori Kritis Morfologi dan Sintaksis Bahasa Indonesia. Flores: Nusa Indah.

Sugono, Dendy. 1995. Pelesapan Subjek dalam Bahasa Indonesia. Jakarta: Pusat Pembinaan dan Pengembangan Bahasa 
Arkhais, Vol. 06 No. 1 Januari_Juni 2015

1992. "TipeKlausaBahasa Indonesia”. Jakarta: Pusat Pembinaan dan Pengembangan Bahasa. 